\title{
Low-intensity laser therapy improves tetanic contractions in mouse anterior tibialis muscle injected with Bothrops jararaca snake venom
}

\author{
Vania Maria de Araújo Giaretta, Luiz Prudêncio Santos, Ana Maria Barbosa, Stephen Hyslop, \\ Alexandre Pinto Corrado, Milene Sanches Galhardo, Renata Amadei Nicolau*, José Carlos Cogo
}

\begin{abstract}
Introduction: Envenomation by Bothrops snakes can produce local pain, edema, hemorrhage and myonecrosis. However, standard antivenom therapy is generally ineffective in neutralizing these effects so that alternative methods of treatment have been investigated. In experimental animals, low-level laser therapy (LLLT) attenuates the local effects of Bothrops venoms, but the benefits of LLLT on muscle function after envenomation are unclear. In this study, we examined the influence of LLLT on the contractile activity of mouse skeletal muscle injected with venom from Bothrops jararaca, the principal cause of snakebite in southeastern Brazil. Methods: Twenty-seven male mice were used. Mice were injected with venom $(40 \mu \mathrm{g}$ in $50 \mu \mathrm{l})$ in the right anterior tibialis muscle, after which the muscle tendon was exposed, connected to an isometric transducer and subjected to a resting tension of $1 \mathrm{~g}$. A bipolar electrode was attached to the tibial nerve for electrical stimulation. The mice were randomly allocated to five groups: A - Control $(\mathrm{n}=3), \mathrm{B}-$ Venom $3 \mathrm{~h}(\mathrm{n}=6)$, C - Venom 9 h $(n=6), D-$ Venom + Laser 3 h $(n=6), E-$ Venom + Laser 9 h $(n=6)$. Results: The two groups that received LLLT post-venom showed improved muscle contraction and contracture in relation to muscle treated with venom alone. Conclusion: These results indicate that LLLT can improve muscle function after damage induced by B. jararaca venom.
\end{abstract}

Keywords: Bothrops jararaca, Low-level laser therapy, Muscle activity, Muscle fatigue, Snake venom, Tetanus.

\section{Introduction}

Bothrops snakes account for $90 \%$ of venomous snakebites in Brazil, with Bothrops jararaca being responsible for most of these cases, especially in southeastern Brazil (Brasil, 2011; França and Málaque, 2009; Leobas et al., 2016). Envenomation by Bothrops species can result in local effects (pain, edema, inflammation, hemorrhage and necrosis) and systemic effects (coagulopathy, systemic hemorrhage, circulatory shock and renal damage) (França and Málaque, 2009; Warrell, 2004). In severe cases of envenoming, myonecrosis mediated predominantly by basic myotoxic phospholipases $\mathrm{A}_{2}\left(\mathrm{PLA}_{2}\right)$ in these venoms (Gutiérrez and Ownby, 2003; Montecucco et al., 2008) can result in important loss of muscle mass, with permanent damage to the bitten limb and loss of function. Part of this myotoxicity is attributable to ischemia caused by impaired circulation as a result of microvascular damage (Gutiérrez and Ownby, 2003; Queiróz et al., 1984).

The most effective treatment for envenomation by Bothrops species is antivenom therapy. However, despite its effectiveness in neutralizing systemic effects such as coagulopathy (França and Málaque, 2009;
Warrell, 2004), antivenom is generally ineffective in neutralizing local reactions (Barbosa et al., 2009; Guimarães-Souza et al., 2011; Nadur-Andrade et al., 2012; Pereira et al., 2009; Picolo et al., 2002). Indeed, a major problem in the treatment of Bothrops venom-induced myonecrosis is the rapid onset of this damage (within $15 \mathrm{~min}$ of venom injection) that makes treatment virtually impossible (Gutiérrez et al., 2007). Consequently, various alternatives have been investigated to reduce the local effects of myotoxicity caused by bothropic venoms, including the use of medicinal plants (Cavalcante et al., 2007; Collaço et al., 2012a; 2012b; Ferraz et al., 2012; 2014; Pereira et al., 2012; Tribuiani et al., 2014) and substances such as heparin and polyanions (Lomonte et al., 1994; Melo et al., 1993). In addition, low-intensity laser therapy (LLLT) has been investigated as a potential treatment for experimental envenomation (Barbosa et al., 2008; 2009; 2010; Doin-Silva et al., 2009; Dourado et al., 2003; Nadur-Andrade et al., 2012).

The effects of LLLT on biological tissues are very broad and induce trophic-regenerative, anti-inflammatory and analgesic actions, as well as 
enhanced local microcirculation, as demonstrated by studies in vitro and in vivo (Barbosa-Souza et al., 2011; Oliveira et al., 2013). This beneficial effect on the microcirculation is related to an indirect action of the laser on precapillary sphincters through the release of chemical mediators that maintain a functional local peripheral microcirculation (Maier et al., 1990; Miró et al, 1984). In spite of various studies have examined the potentially beneficial effects of LLLT in animal models of pain, edema, local inflammation, hemorrhage and myonecrosis (Medeiros et al., 2010; Oliveira et al., 2013), to date there has been no assessment of the influence of LLLT on the contractility of venom-injected skeletal muscle. In this study, we examined the effect of LLLT on the function of mouse tibial muscle injected with $B$. jararaca venom.

\section{Methodology}

Twenty-seven male Swiss mice (18-22 g), obtained from Animais de Laboratório (Anilab, Paulínia, SP), were housed six/cage in the Laboratory of Physiology and Pharmacodynamics of the Institute for Research and Development at the Universidade do Vale do Paraíba (UNIVAP). The mice were maintained on a $12 \mathrm{~h} \mathrm{light/dark} \mathrm{cycle} \mathrm{at} 22-26^{\circ} \mathrm{C}$, with free access to food and water. Prior to use, the mice were randomly allocated to five groups: A - Control ( $\mathrm{n}=3), \mathrm{B}-$ Venom $3 \mathrm{~h}(\mathrm{n}=6), \mathrm{C}-$ Venom $9 \mathrm{~h}(\mathrm{n}=6), \mathrm{D}-$ Venom + Laser $3 \mathrm{~h}$ $(\mathrm{n}=6)$ and $\mathrm{E}-$ Venom + Laser $9 \mathrm{~h}(\mathrm{n}=6)$. The animal experiments approved by the institutional Committee for Ethics in Animal Use at UNIVAP (protocol no. CEUA/2012/A01). The experiments were done within the ethical guidelines of the Brazilian Society for Laboratory Animal Science (SBCAL).

Venom was extracted from adult specimens of B. jararaca maintained at the serpentarium at UNIVAP. The venom was extracted manually and stored at $-80^{\circ} \mathrm{C}$ until lyophilized. Storage was subsequently at $4{ }^{\circ} \mathrm{C}$ until use.

For the experiments, the right anterior tibialis muscle was used, as described by Giaretta et al. (2015). Mice were injected with $B$. jararaca venom (40 $\mu \mathrm{g}$ in $50 \mu \mathrm{l}$ of $0.9 \%$ saline); this dose of venom was chosen based on previous publications by our group (Barbosa et al., 2010; Dourado et al., 2011). The tibialis muscle of control mice was injected with an equal volume of $0.9 \%$ saline. Mice treated with LLLT received irradiation (InGaAlP laser equipment, Twin Flex Evolution ${ }^{\circledR}$, MMOptics) 30 min after venom injection, operated in direct contact mode (parameters described in Table 1).

At $3 \mathrm{~h}$ and $9 \mathrm{~h}$ post-injection, the mice were anesthetized (xylazine $-20 \mathrm{mg} / \mathrm{kg}$, i.p.,
Table 1. Laser parameters

\begin{tabular}{cc}
\hline Parameters & Values \\
\hline Energy density $\left(\mathrm{J} / \mathrm{cm}^{2}\right)$ & 3 \\
Energy $(\mathrm{J})$ & 0.6 \\
Power $(\mathrm{mW})$ & 35 \\
Irradiation time $(\mathrm{s})$ & 17 \\
Spot $\left(\mathrm{cm}^{2}\right)$ & 0.19 \\
Wavelength $(\mathrm{nm})$ & $660 \pm 5$ \\
\hline
\end{tabular}

ketamine $-100 \mathrm{mg} / \mathrm{kg}$, i.p., atropine $-0.25 \mathrm{mg} / \mathrm{kg}$, i.p., and diazepam $-5 \mathrm{mg} / \mathrm{kg}$, i.p.), fixed on a surgical table and the tendon of the right anterior tibialis muscle and the tibial nerve were exposed. In the region of insertion close to the metatarsal plantar region, the muscle tendon was connected to an isometric transducer and the nerve was connected to a bipolar electrode.

The muscle was subjected to a constant tension of $1 \mathrm{~g}$ and stimulated indirectly by individual pulses from a Grass Technologies model S48 ${ }^{\circledR}$ square pulse stimulator. Pulses ( $4-8 \mathrm{mV}, 0.2 \mathrm{~Hz}, 2 \mathrm{~ms}$ ) were applied for $3 \mathrm{~min}$ to determine the minimum and maximum voltages needed to induce muscle contraction with recruitment of all fibers (Doin-Silva et al., 2009; Lopes-Martins et al., 2006). Tetanic stimuli were applied by increasing the frequency to $50 \mathrm{~Hz}$ for $10 \mathrm{~s}$ and the tetanic response was recorded. Six tetanic stimuli were applied at $3 \mathrm{~min}$ intervals. During these intervals, muscle intactness and normal contractility were assessed using the stimulus parameters described above $(4-8 \mathrm{mV}, 0.2 \mathrm{~Hz}, 2 \mathrm{~ms})$. The tetanic contractions were recorded via an isometric force transducer (model 7003, Ugo Basile ${ }^{\circledR}$ ) coupled to a Gemini 7070 flat-bed recorder (Ugo Basile ${ }^{\circledR}$, Varese, Italy). The tetanic responses were analyzed by measuring the amplitude of the first peak of contracture to the electrical stimulus.

At the end of the stimulation protocols, the anesthetized mice were killed with an overdose of $10 \% \mathrm{KCl}$ administered intracardially (Barbosa et al., 2009; 2010; Barbosa-Souza et al., 2011; Santos et al., 2010). The muscles (control and venom-treated) were removed and fixed in $4 \%$ formaldehyde for $24 \mathrm{~h}$, followed by routine processing for dehydration and embedding in paraffin or paraplast. Sections $5 \mu \mathrm{m}$ thick were cut with a microtome, mounted on microscope slides and stained with hematoxylin-eosin (HE). The sections were examined with a Leica DM2500 microscope fitted with a Leica DFC425 camera. Aspects analyzed included the occurrence of myonecrosis, the intactness of the cell membrane, the position of the nuclei and the presence of cellular infiltration. Representative images were photographed and processed with Leica LASV ${ }^{\circledR}$ software. In addition, the muscle fiber diameters (longitudinal section) 
and area (cross-section) were quantified, using ImageJ $1.49 \mathrm{t}$ software. The changes in muscle fiber morphometry were assessed by measuring the fiber diameter in 6 non-overlapping fields per section in 10 non-consecutive sections for each muscle (total of 60 fibers/mouse). The fibers area was measured in 10 fibers/section/animal.

The results were expressed as the mean \pm standard error of the mean (SEM). Statistical comparisons between the control (saline), venom alone and venom + laser groups were done using ANOVA followed by the Tukey-Kramer post-test for multiple comparisons. Values of $\mathrm{p}<0.05$ were considered significant. All data analyses were done using Prism ${ }^{\circledR}$ v.5.0 (GraphPad, La Jolla, CA, USA).

\section{Results}

Figure 1 shows representative recordings of the tetanic responses of saline- (control) and venom-injected muscles. Control muscle showed consistent, reproducible responses to a series of six tetanic trains (Figure 1A), indicating that the muscle was not damaged by repeated stimulations. In contrast, $3 \mathrm{~h}$ and $9 \mathrm{~h}$ after venom injection the tibial muscle showed no responses to low voltage or tetanic stimuli
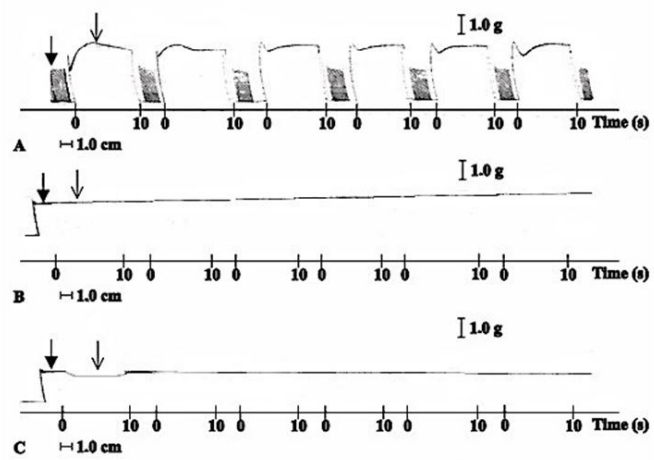

I $1.0 \mathrm{~g}$
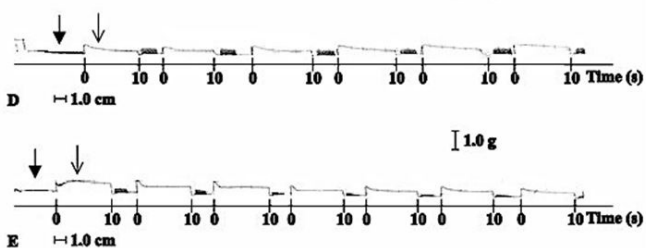

Figure 1. Myographic records of electrically-induced tetanic contractions in mouse tibialis muscle. (A) Control (saline; $\mathrm{n}=3$ ); (B) Venom $3 \mathrm{~h}(\mathrm{n}=6)$; (C) Venom $9 \mathrm{~h}(\mathrm{n}=6)$; (D) Venom + Laser $3 \mathrm{~h}$ $(\mathrm{n}=6)$; and (E) Venom + Laser $9 \mathrm{~h}(\mathrm{n}=6)$. The baseline in control preparations remained stable throughout the experiment, indicating that the muscle did not go into contracture and was not injured during repeated stimulations. Venom-injected muscles treated with laser showed contractions and tetanus. In each record: first (dark) arrow - baseline and second (light) arrow - response to tetanic stimulus. The records are representative of the number of experiments indicated.
(Figure 1B, C), which suggested that the venom had caused important damage to the muscle contractile machinery. Treatment with LLLT 30 min after venom injection followed by assessment of muscle function $3 \mathrm{~h}$ and $9 \mathrm{~h}$ post-venom revealed small but significant recovery of the tetanic response (by $10 \%$ and $15 \%$, respectively) compared to the responses to venom alone (Figures 1D, E, 2 and 3).

Histological analysis of saline-injected (control) muscle revealed myocytes with a normal appearance (intact cell membrane and muscle fibers, well-defined muscle fascicles, peripherally located nuclei and a normal interstitial space) (Figure 4A, B). In contrast to this normal appearance, $3 \mathrm{~h}$ after venom injection

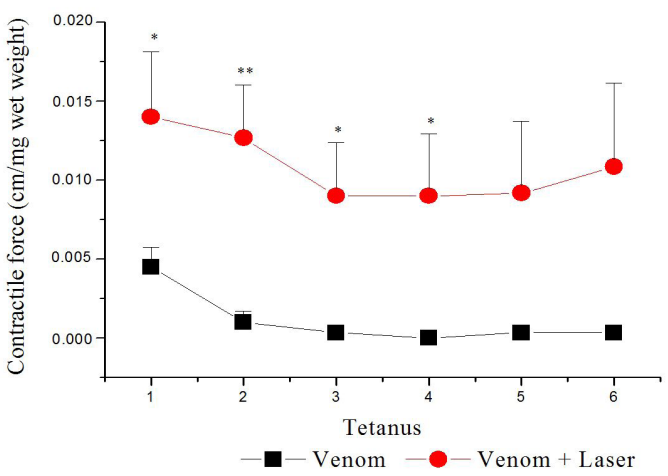

Figure 2. Contractile force generated by tetanic responses in mouse tibial muscle $3 \mathrm{~h}$ after injection of $B$. jararaca venom $(40 \mu \mathrm{g})(\boldsymbol{-})$ and venom followed by treatment with LLLT $(\bullet)$. In contrast to venom alone, venom-injected muscle exposed to LLLT showed enhanced tetanic responses. The contractile force (muscle tension) was calculated from the initial peak of the tetanic response. The points are the mean \pm SEM. $* \mathrm{p}<0.05$ and $* * \mathrm{p}<0.01$ compared to venom alone.

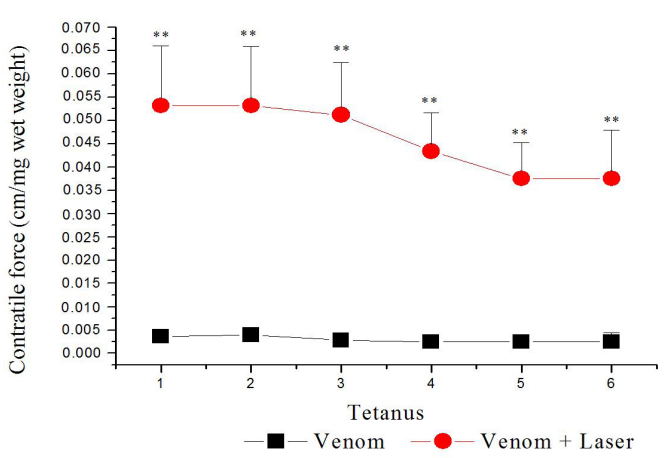

Figure 3. Contractile force generated by tetanic responses in mouse tibial muscle $9 \mathrm{~h}$ after injection of $B$. jararaca venom $(40 \mu \mathrm{g})(-)$ and venom followed by treatment with $\operatorname{LLLT}(\bullet)$. In contrast to venom alone, venom-injected muscle exposed to LLLT showed enhanced tetanic responses. The contractile force (muscle tension) was calculated from the initial peak of the tetanic response. The points are the mean \pm SEM. $* * \mathrm{p}<0.01$ compared to venom alone. 

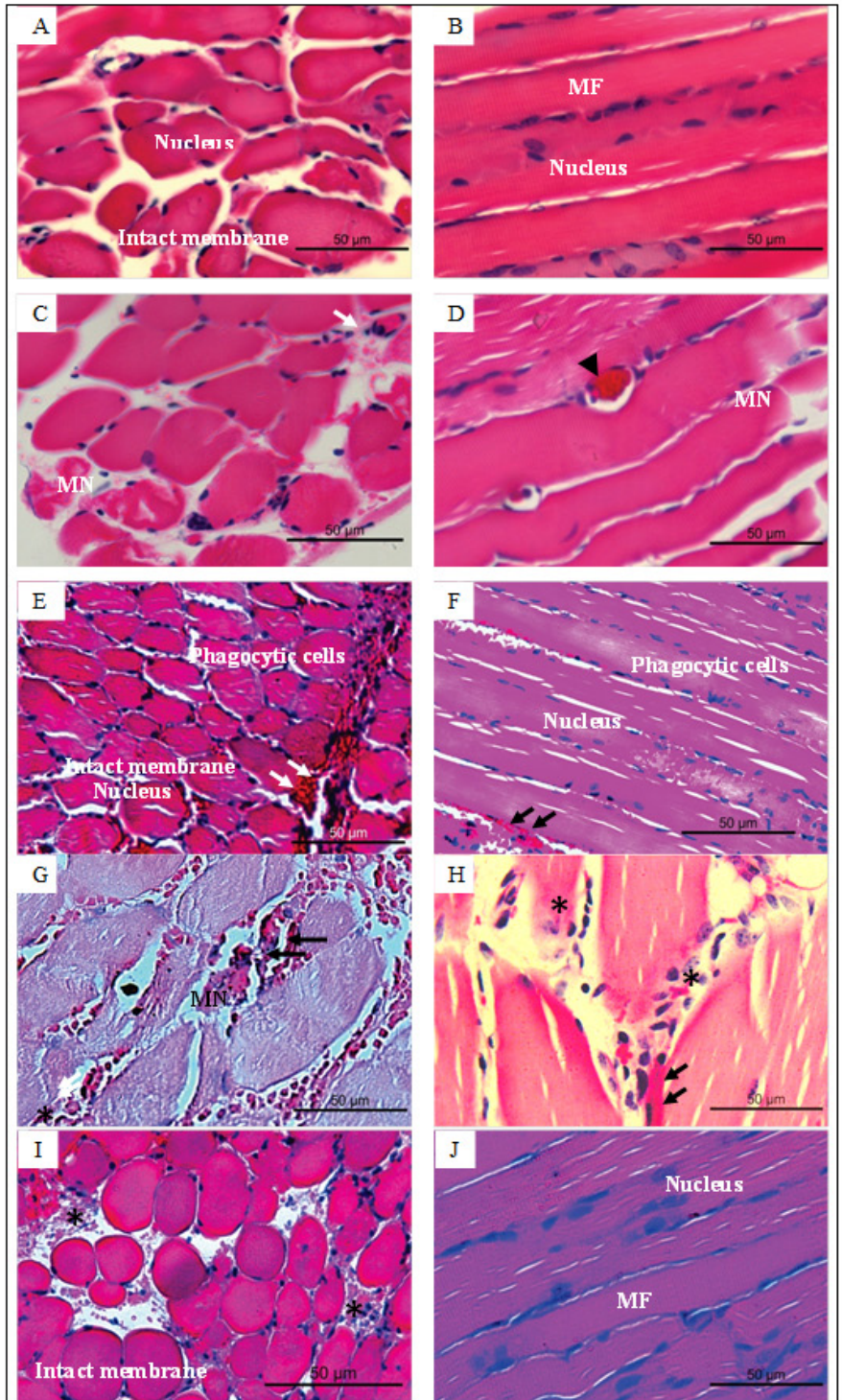

Figure 4. Histological sections of mouse tibial muscle injected with B. jararaca venom (40 $\mu \mathrm{g})$. (A, B): Control muscles $3 \mathrm{~h}$ after injection of $0.9 \%$ saline showing muscle fibers (MF) of uniform diameter with peripheral nuclei and an intact cell membrane. (C, D): Venom-treated muscle $3 \mathrm{~h}$ after venom injection. Note the myonecrosis (disruption of the cell membrane) and hemorrhage (red blood cells in the interstitial space). (E, F): Venom-treated muscle exposed to LLLT and analyzed $3 \mathrm{~h}$ after venom injection. Note the intact fibers, peripherally located nuclei, undamaged cell membrane and presence of inflammatory cells in the interstitial space. $(\mathrm{G}, \mathrm{H})$ : Venom-treated muscle $9 \mathrm{~h}$ after venom injection. The histological changes were similar to those at $3 \mathrm{~h}$, but there was a marked inflammatory infiltrate. (I, J): Venom-treated muscle exposed to LLLT and analyzed $9 \mathrm{~h}$ after venom injection. Note the unaltered cell membrane and the presence of hemorrhage and inflammatory cells. Treatment with LLLT attenuated the venom-induced myonecrosis but did not affect the hemorrhage or infiltration of inflammatory cells. Blood vessel - arrowhead; Hemorrhage - arrow; Inflammatory infiltrate - asterisks; Myonecrosis - MN. Scale bars $=50 \mu \mathrm{m}$.

there was muscle fiber disorganization and degradation indicative of myonecrosis; there was also hemorrhage, cellular infiltration and an increase in fiber diameter suggestive of intracellular edema formation (Figures 4C, D, 5A, B). Similar changes occurred at $9 \mathrm{~h}$ post-venom, but were less marked (Figure $4 \mathrm{G}, \mathrm{H}$ ).
In venom-injected muscle treated with LLLT and analyzed $3 \mathrm{~h}$ post-venom, there was less myonecrosis but inflammatory (phagocytic) cells were observed (Figure 4E, F). At $9 \mathrm{~h}$ post-venom, LLLT-treated muscle showed an intact cell membrane (no myonecrosis), cellular infiltration and a small amount of hemorrhage 
(Figure 4I, J). Overall, at both time intervals, there was attenuation of venom-induced myonecrosis. Histomorphometric analysis showed a significant decrease in the diameter and area of muscle fibers in mice treated with LLLT $(3 \mathrm{~h}$ ) compared to those treated with venom alone; this improvement persisted after $9 \mathrm{~h}$, but was less marked than at $3 \mathrm{~h}$, probably because of partial recovery in the venom-treated muscles, i.e., the diameter and area in venom-treated muscle were greater at $9 \mathrm{~h}$ compared to $3 \mathrm{~h}$ (Figure 5A, B).

\section{Discussion}

LLLT is a non-invasive, low-cost procedure that has been widely used in clinical practice to relieve pain and stimulate tissue regeneration (Buso, 2006; Dall-Agnol et al., 2009; Fikackova et al., 2006; Kato et al., 2006; Medeiros et al., 2010; Oliveira et al., 2013; Piva et al., 2011). Laser light interacts with biological tissues to produce significant beneficial therapeutic effects in various physiological systems (Leal et al., 2010; Piva et al., 2011). Lopes-Martins et al. (2006) found that GaAlAs laser at $\lambda 630-680 \mathrm{~nm}$ protected against muscle damage, with a concomitant decrease in creatine kinase release, stimulated the release of cGMP to cause local vasodilatation and helped to

$\mathbf{A}$

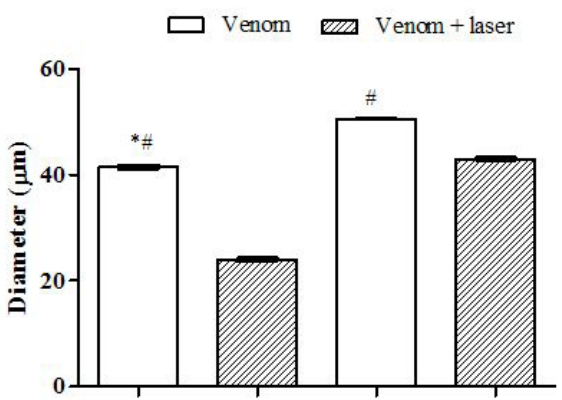

B

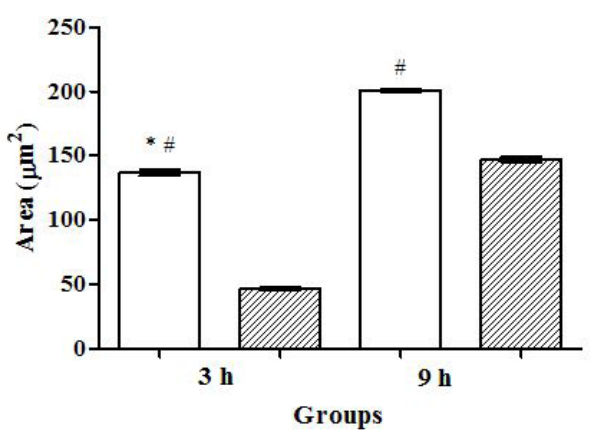

Figure 5. Histomorphometric analysis of venom and venom + laser treated tibial muscles $3 \mathrm{~h}$ and $9 \mathrm{~h}$ after LLLT. Muscle fiber diameters (A) and area (B) were quantified in longitudinal and cross-sections $(\mathrm{n}=10$ sections/mouse) and the columns represent the mean \pm SEM. $\mathrm{p}<0.0001$ : * vs 9h; \# vs laser. maintain muscle contractile strength in rats. More recently, Giaretta et al. (2015) observed that LLLT improved muscle function in mice, as assessed by the enhanced tetanic response and resistance to fatigue.

Based on studies of the beneficial effects of LLLT in a variety of models, various experimental investigations have shown that LLLT can reduce the myonecrosis, edema and inflammation induced by snake venoms (Barbosa et al., 2009; 2010; Barbosa-Souza et al., 2011; Doin-Silva et al., 2009; Oliveira et al., 2013). Dourado et al. (2003) examined the effects of laser irradiation with GaAs $4 \mathrm{~J} / \mathrm{cm}^{2}$ on the myonecrosis caused by Bothrops moojeni snake venom in mouse gastrocnemius muscle. Subsequently, Barbosa et al. $(2008 ; 2010)$ observed that GaAs laser significantly decreased the myonecrosis caused by Bothrops jararacussu snake venom in mice. Although these studies reported the recovery of muscle cell structures, they did not assess possible improvements in muscle function. These beneficial effects of laser treatment on venom-induced damage are apparently not mediated by a direct action of laser light on venom activities since Barbosa et al. (2009) showed that prior irradiation of $B$. jararacussu venom did not adversely affect the myotoxicity of this venom.

As shown here, the intramuscular injection of $B$. jararaca venom adversely affected muscle contractility (electrically-induced contractions and contractures). Treatment with LLLT partially restored this muscle dysfunction $3 \mathrm{~h}$ and $9 \mathrm{~h}$ after venom injection, probably by reducing the muscle fatigue. This conclusion is supported by the findings of Leal et al. (2009), who reported that phototherapy (infrared radiation) attenuated the skeletal muscle fatigue in biceps muscles of professional male volleyball players. The possible cellular mechanisms involved in this enhanced resistance to fatigue have been investigated in recent studies (Giaretta et al., 2015; Kelencz et al., 2010; Maciel et al., 2013; Muñoz et al., 2013; Reis et al., 2015). Passarella and Karu (2014) reported that mitochondria respond to low intensity light and that this response increases ATP production and facilitates cell multiplication. Albuquerque-Pontes et al. (2015) also observed increased cytochrome c oxidase activity in response to a $660 \mathrm{~nm}$ laser with an output of $1 \mathrm{~J}$. These authors noted a significant increase in the percentage of muscle fibers with $>50 \%$ staining for cytochrome c oxidase within 5 min after LLLT; the enhanced cytochrome c oxidase activity probably facilitated the transfer of protons and electrons, thereby accelerating the rate of oxidative metabolism. This led to an increase in ATP that in turn enhanced cellular activity and muscle contractility. 
Histological analysis of muscle injected with B. jararaca venom alone revealed myonecrosis, similar to but less marked than that caused by the venoms of B. jararacussu (Barbosa et al., 2009; Doin-Silva et al., 2009) and B. moojeni (Dourado et al., 2003). Treatment with LLLT attenuated this myonecrosis, as also observed by Doin-Silva et al. (2009) for B. jararacussu venom in rats. Dourado et al. (2003) reported that $\mathrm{GaAs}$ and $\mathrm{HeNe}$ laser therapy significantly reduced the inflammation and myonecrosis caused by $B$. moojeni venom, with GaAs laser being more effective than HeNe laser. Similarly, Doin-Silva et al. (2009) found that $\mathrm{HeNe}$ laser attenuated the damage to rat gastrocnemius muscle and associated nerve caused by $B$. jararacussu venom; these authors also noted an improvement in the contractility of irradiated muscle compared to muscle treated with venom alone. Barbosa et al. (2010) reported that GaAs laser reduced the edema, inflammation and myonecrosis caused by $B$. jararacussu venom in rat paw.

As shown here, LLLT reduced the diameter and area of venom-treated muscle fibers in relation to venom alone at $3 \mathrm{~h}$, with the attenuation being less marked at $9 \mathrm{~h}$. This attenuation by LLLT was accompanied by improved tetanic responses compared to venom alone. This finding suggests that LLLT had a beneficial effect on muscle contractility in the presence of venom.

Overall, the results of this study indicate that treatment with LLLT attenuated the myonecrosis caused by $B$. jararaca venom and partially but significantly reversed the venom-induced dysfunction in muscle contractility. The ability of LLLT to partially restore the function of envenomed muscle suggests that this intervention could be a potentially beneficial ancillary procedure for treating the myonecrosis and muscle dysfunction caused by Bothrops venoms.

\section{References}

Albuquerque-Pontes GM, Vieira RP, Tomazoni SS, Caires CO, Nemeth V, Vanin AA, Santos LA, Pinto HD, Marcos RL, Bjordal JM, Carvalho PTC, Leal-Junior ECP. Effect of pre-irradiation with different doses, wavelengths, and application intervals of low-level laser therapy on cytochrome c oxidase activity in intact skeletal muscle of rats. Lasers in Medical Science. 2015; 30(1):59-66. http://dx.doi.org/10.1007/ s10103-014-1616-2. PMid:24957189.

Barbosa AM, Villaverde AB, Guimarães-Sousa L, Soares AM, Zamuner SF, Cogo JC, Zamuner SR. Low-level laser therapy decreases local effects induced by myotoxins isolated from Bothrops jararacussu snake venom. The Journal of Venomous Animals and Toxins Including Tropical Diseases. 2010; 16(3):470-9. http://dx.doi.org/10.1590/ S1678-91992010000300014

Barbosa AM, Villaverde AB, Guimarães-Souza L, Munin E, Fernandes CM, Cogo JC, Zamuner SR. Effect of the low level laser therapy in the myonecrosis induced by Bothrops jararacussu snake venom. Photomedicine and Laser Surgery. 2009; 27(4):591-7. http://dx.doi.org/10.1089/pho.2008.2296. PMid:19530909.

Barbosa AM, Villaverde AB, Guimarães-Souza L, Ribeiro W, Cogo JC, Zamuner SR. Effect of low-level laser therapy in the inflammatory response induced by Bothrops jararacussu snake venom. Toxicon. 2008; 51(7):1236-44. http://dx.doi. org/10.1016/j.toxicon.2008.02.007. PMid:18439641.

Barbosa-Souza V, Contin DK, Bonventi W Fo, Araújo AL, Irazusta SP, Cruz-Höfling MA. Osteopontin, a chemotactic protein with cytokine-like properties, is up-regulated in muscle injury caused by Bothrops lanceolatus (fer-de-lance) snake venom. Toxicon. 2011; 58(5):398-409. http://dx.doi. org/10.1016/j.toxicon.2011.07.011. PMid:21839764.

Brasil. Manual de diagnóstico e tratamento de acidentes por animais peçonhentos. 2. ed. Brasília: Fundação Nacional de Saúde; 2011 [cited 2011 Jun 16]. 120 p. Available from: http://dtr2004.saude.gov.br/sinanweb/

Buso NC. Avaliação da ação do laser arseneto de gálio904nm no processo de reparação do tendão de Aquiles em ratos [dissertation]. São José dos Campos: Universidade do Vale do Paraíba; 2006.

Cavalcante WL, Campos TO, Dal Pai-Silva M, Pereira PS, Oliveira CZ, Soares AM, Gallacci M. Neutralization of snake venom phospholipase $\mathrm{A}_{2}$ toxins by aqueous extract of Casearia sylvestris (Flacourtiaceae) in mouse neuromuscular preparation. Journal of Ethnopharmacology. 2007; 112(3):490-7. http://dx.doi.org/10.1016/j.jep.2007.04.002. PMid:17540522.

Collaço RCO, Cogo JC, Rodrigues-Simioni L, Rocha T, Oshima-Franco Y, Randazzo-Moura P. Protection by Mikania laevigata (guaco) extract against the toxicity of Philodryas olfersii snake venom. Toxicon. 2012b; 60(4):614-22. http:// dx.doi.org/10.1016/j.toxicon.2012.05.014. PMid:22677807.

Collaço RCO, Leite GB, Cogo JC, Hyslop S, Rocha T, Randazzo-Moura P, Rodrigues-Simioni L. Neuromuscular activity of Bothrops fonsecai snake venom and its neutralization by commercial Bothropic antivenom. Toxicon. 2012a; 60(2):174-5. http://dx.doi.org/10.1016/j.toxicon.2012.04.157.

Dall-Agnol MA, Nicolau RA, Lima JC, Munin E. Comparative analysis of coherent light action (laser) versus non-coherent light (LED) for tissues repair in diabetic rats. Lasers in Medical Science. 2009; 24(6):909-16. http://dx.doi.org/10.1007/ s10103-009-0648-5. PMid:19238507.

Doin-Silva R, Baranauskas V, Rodrigues-Simioni L, Cruz-Höfling MA. The ability of low level laser therapy to prevent muscle tissue damage induced by snake venom. Photochemistry and Photobiology. 2009; 85(1):63-9. http:// dx.doi.org/10.1111/j.1751-1097.2008.00397.x. PMid:18643907.

Dourado DM, Fávero S, Baranauskas V, Cruz-Höfling MA. Effects of the Ga-As laser irradiation on myonecrosis caused by Bothrops moojeni snake venom. Lasers in Surgery and Medicine. 2003; 33(5):352-7. http://dx.doi.org/10.1002/ lsm.10237. PMid:14677163.

Dourado DM, Favero S, Matias R, Carvalho PTC, Cruz-Höfling MA. Low-level laser therapy promotes vascular endothelial growth factor receptor-1 expression in endothelial and nonendothelial cells of mice gastrocnemius exposed to snake venom. Photochemistry and Photobiology. 2011; 87(2):419- 
26. http://dx.doi.org/10.1111/j.1751-1097.2010.00878.x. PMid:21166811.

Ferraz MC, Parrilha LAC, Moraes MSD, Amaral J Fo, Cogo JC, Santos MG, Franco LM, Groppo FC, Puebla P, Feliciano AS, Oshima-Franco Y. The effect of lupane triterpenoids (Dipteryx alata Vogel) in the in vitro neuromuscular blockade and myotoxicity of two snake venoms. Current Organic Chemistry. 2012; 16(1385-2728):2717-23. http://dx.doi. org/10.2174/138527212804004481.

Ferraz MC, Yoshida EH, Tavares RVS, Cogo JC, Belo CAD, Franco LM, Santos MG, Hyslop S, Puebla P, Feliciano AS, Oshima-Franco Y. An isoflavone from Dipteryx alata vogel is active against paralysis of Bothrops jararacussu snake venom and Bothrops venom-induced myonecrosis. Molecules (Basel, Switzerland). 2014; 19(5):5790-805. http://dx.doi. org/10.3390/molecules19055790. PMid:24806579.

Fikackova H, Dostalova L, Vosicka R, Peterova V, Navratil L, Lesak J. Arthralgia of the temporomandibular joint and low-level laser therapy. Photomedicine and Laser Surgery. 2006; 24(4):522-7. http://dx.doi.org/10.1089/pho.2006.24.522. PMid:16942435.

França FOS, Málaque CMS. Acidente botrópico. In: Cardoso JLC, França FOS, Wen FH, Málaque CMS, Haddad V Jr, editors. Animais peçonhentos no Brasil: biologia, clínica e terapêutica dos acidentes. São Paulo: Sarvier/FAPESP; 2009. p. 81-95.

Giaretta VMA, Santos LP, Barbosa AM, Hyslop S, Corrado AP, Nicolau RA, Cogo JC. Effect of low-level laser therapy (GaAlAs - $\lambda 660 \mathrm{~nm}$ ) on muscle function. Research in Biomedical Engineering. 2015; 31(3):241-8. http://dx.doi. org/10.1590/2446-4740.0736.

Guimarães-Souza L, Dale CS, Nadur-Andrade N, Barbosa AM, Cogo JC, Zamuner SR. Low-level laser therapy reduces edema, leukocyte influx and hyperalgesia induced by Bothrops jararacussu snake venom. Clinical and Experimental Medical Letters. 2011; 52(3-4):97-102.

Gutiérrez JM, Lomonte B, León G, Rucavado A, Chaves F, Ângulo Y. Trends in snakebite envenomation therapy: scientific, technological and public health considerations. Current Pharmaceutical Design. 2007; 13(28):2935-50. http:// dx.doi.org/10.2174/138161207782023784. PMid:17979738.

Gutiérrez JM, Ownby CL. Skeletal muscle degeneration induced by venom phospholipases $\mathrm{A}_{2}$ : insights into the mechanisms of local and systemic myotoxicity. Toxicon. 2003; 42(8):915-31. http://dx.doi.org/10.1016/j.toxicon.2003.11.005. PMid:15019491.

Kato MT, Kogawa EM, Santos CN, Conti PCR. TENS and lowlevel laser therapy in the management of temporomandibular disorders. Journal of Applied Oral Science. 2006; 14(2):1305. http://dx.doi.org/10.1590/S1678-77572006000200012. PMid:19089044.

Kelencz CA, Munoz ISS, Amorim CF, Nicolau RA. Effect of low-power gallium-aluminium-arsenium non-coherent light $(640 \mathrm{~nm})$ on muscle activity: a clinical study. Photomedicine and Laser Surgery. 2010; 28(5):647-52. http://dx.doi. org/10.1089/pho.2008.2467.

Leal ECP Jr, Lopes-Martins RÁB, Almeida P, Ramos L, Iversen VV, Bjordal JM. Effect of low-level laser therapy (GaAs $904 \mathrm{~nm}$ ) in skeletal muscle fatigue and biochemical markers of muscle damage in rats. European Journal of Applied Physiology. 2010; 108(6):1083-8. http://dx.doi.org/10.1007/ s00421-009-1321-1. PMid:20024577.

Leal ECP Jr, Lopes-Martins RÁB, Baroni BM, Marchi T, Taufer D, Manfro DS, Rech M, Danna V, Grosselli D, Generosi RA, Marcos RL, Ramos L, Bjordal JM. Effect of $830 \mathrm{~nm}$ low-level laser therapy applied before high-intensity exercises on skeletal muscle recovery in athletes. Lasers in Medical Science. 2009; 24(6):857-63. http://dx.doi.org/10.1007/ s10103-008-0633-4. PMid:19057981.

Leobas GF, Feitosa SB, Seibert CS. Accidents by venomous animals in tocantins state: clinical and epidemiological aspects. DESAFIOS: Revista Interdisciplinar da Universidade Federal do Tocantins. 2016; 2(2):269-82. http://dx.doi.org/10.20873/ uft.2359.

Lomonte B, Moreno E, Tarkowski LA, Hanson LA, Maccarana M. Neutralizing interaction between heparins and myotoxin II, a lysine 49 phospholipase $\mathrm{A}_{2}$ from Bothrops asper snake venom. Identification of a heparin-binding and cytolytic toxin region by the use of synthetic peptides and molecular modeling. The Journal of Biological Chemistry. 1994; 269(47):29867-73. PMid:7961981.

Lopes-Martins RÁB, Marcos RL, Leonardo PS, Prianti AC Jr, Muscará MN, Aimbire F, Frigo L, Iversen VV, Bjordal JM. Effect of low-level laser (Ga-Al-As $655 \mathrm{~nm}$ ) on skeletal muscle fatigue induced by electrical stimulation in rats. Journal of Applied Physiology. 2006; 101(1):283-8. http:/ dx.doi.org/10.1152/japplphysiol.01318.2005. PMid:16627677.

Maciel TS, Muñoz ISS, Nicolau RA, Nogueira DV, Hauck LA, Osório R, Paula AR Jr. Phototherapy effect on the muscular activity of regular physical activity practitioners. Lasers in Medical Science. 2013; 29:1145-52.

Maier M, Haina D, Landthaler M. Effect of low energy laser on the growth and regeneration of capillaries. Lasers in Medical Science. 1990; 5(4):381-6. http://dx.doi.org/10.1007/ BF02032595.

Medeiros JL, Nicolau RA, Nicola EMD, dos Santos JN, Pinheiro ALB. Healing of surgical wounds made with $\lambda 970-\mathrm{nm}$ diode laser associated or not with laser phototherapy $(\lambda 655$ $\mathrm{nm})$ or polarized light $(\lambda 400-2000 \mathrm{~nm})$. Photomedicine and Laser Surgery. 2010; 28(4):489-96. http://dx.doi.org/10.1089/ pho.2009.2592. PMid:19857050.

Melo PA, Homsi-Brandeburgo MI, Giglio JR, Suarez-Kurtz G. Antagonism of the myotoxic effects of Bothrops jararacussu venom and bothropstoxin by polyanions. Toxicon. 1993; 31(3):285-91. http://dx.doi.org/10.1016/0041-0101(93)90146-A. PMid:8470133.

Miró L, Coupe M, Charras C, Jambon C, Chevalier JM. Estudio capiloroscópico de la acción de um láser de AsGa sobre la microcirculación. Investigacion y Clinica Laser. 1984; 1(2):9-14.

Montecucco C, Gutiérrez JM, Lomonte B. Cellular pathology induced by snake venom phospholipase $\mathrm{A} 2$ myotoxins and neurotoxins: common aspects of their mechanisms of action. Cellular and Molecular Life Sciences. 2008; 65(18):2897-912. http://dx.doi.org/10.1007/s00018-008-8113-3. PMid:18563294.

Muñoz ISS, Hauck LA, Nicolau RA, Kelencz CA, Maciel TS, Paula, AR. Efeito do laser vs LED na região do infravermelho 
próximo sobre a atividade muscular esquelética estudo clínico. Revista Brasileira de Engenharia Biomédica. 2013; 29:262-8.

Nadur-Andrade N, Barbosa AM, Carlos FP, Lima CJ, Cogo JC, Zamuner SR. Effects of photobiostimulation on edema and hemorrhage induced by Bothrops moojeni venom. Lasers in Medical Science. 2012; 27(1):65-70. http://dx.doi. org/10.1007/s10103-011-0914-1. PMid:21484453.

Oliveira RA, Matos AF, Barros NRB, Fernandes GA, Lima ACG, Nicolau RA. Low-intensity laser therapy and LED (light emitting diode) therapy in mechanical resistance and heating of Rattus norvegicus chest incision with implant of steel wire for sternal suture. Revista Brasileira de Engenharia Biomédica (Impresso). 2013; 29(2):166-74. http://dx.doi. org/10.4322/rbeb.2013.016.

Passarella S, Karu T. Absorption of monochromatic and narrow band radiation in the visible and near IR by both mitochondrial and non-mitochondrial photoacceptors results in photobiomodulation. Journal of Photochemistry and Photobiology. B, Biology. 2014; 140:344-58. http://dx.doi. org/10.1016/j.jphotobiol.2014.07.021. PMid:25226343.

Pereira DM, Cogo JC, Zamuner SR. Efeito antiedematogênico da planta Vernonia scorpioides frente ao veneno de Bothrops fonsecai e carragenina. ConScientiae Saúde (Impresso). 2012; 11(1):46-52. http://dx.doi.org/10.5585/ConsSaude.v11n1.2862.

Pereira IC, Barbosa AM, Salvador MJ, Soares AM, Ribeiro W, Cogo JC, Zamuner SR. Anti-inflammatory activity of Blutaparon portulacoides ethanolic extract against the inflammatory reaction induced by Bothrops jararacussu venom and isolated myotoxins BthTX-I and II. Journal of Venomous Animals and their Toxins including Tropical Diseases. 2009; 15(3):527-45. http://dx.doi.org/10.1590/ S1678-91992009000300013.

Picolo G, Chacur M, Gutiérrez JM, Teixeira CFP, Cury Y. Evaluation of antivenoms in the neutralization of hyperalgesia and edema induced by Bothrops jararaca and Bothrops asper snake venoms. Brazilian Journal of Medical and Biological Research. 2002; 35(10):1221-8. http://dx.doi.org/10.1590/ S0100-879X2002001000016. PMid:12424496.
Piva JAAC, Abreu EMC, Silva VS, Nicolau RA. Ação da terapia com laser de baixa potência nas fases iniciais do reparo tecidual: princípios básicos. Anais Brasileiros de Dermatologia. 2011; 86(5):947-54. http://dx.doi.org/10.1590/ S0365-05962011000500013. PMid:22147035.

Queiróz LS, Santo-Neto H, Rodrigues-Simioni L, PradoFranceschi J. Muscle necrosis and regeneration after envenomation by Bothrops jararacussu snake venom. Toxicon. 1984; 22(3):339-46. http://dx.doi.org/10.1016/00410101(84)90077-1. PMid:6474488.

Reis MCR, Andrade EAF, Borges ACL, Souza DQ, Lima FPS, Nicolau RA, Andrade AO, Lima MO. Immediate effects of low level laser $(808 \mathrm{~nm})$ on fatigue and strength of spastic muscle. Lasers in Medical Science. 2015; 30(3):1089-96. http://dx.doi.org/10.1007/s10103-014-1702-5.

Santos CM, Pereira ES, Rabelo NS, Zamuner SR, Barbosa AM, Cogo JC. Efeito do laser de baixa intensidade e LED na atividade hemorrágica induzida pelo veneno da serpente Bothrops jararaca. In: Anais do $14^{\circ}$ Encontro Latino Americano de Iniciação Científica e $10^{\circ}$ Encontro Latino Americano de Pós-Graduação; 2010; São José dos Campos, Brasil. São José dos Campos: UNIVAP; 2010. p. 1-4.

Tribuiani N, Da Silva A, Ferraz M, Silva M, Bentes AP, Graziano T, Dos Santos M, Cogo JC, Varanda E, Groppo F, Cogo K, Oshima-Franco Y. Vellozia flavicans Mart. ex Schult. hydroalcoholic extract inhibits the neuromuscular blockade induced by Bothrops jararacussu venom. BMC Complementary and Alternative Medicine (Online). 2014; 14(1):48. http://dx.doi.org/10.1186/1472-6882-14-48. PMid:24507387.

Warrell DA. Snakebites in Central and South America: epidemiology, clinical features and clinical management. In: Campbell JA, Lamar WW, editors. Venomous reptiles of the Western Hemisphere. Ithaca: Comstock Publishers/Cornell University Press; 2004. vol. 2, p. 709-61.

\footnotetext{
Authors

Vania Maria de Araújo Giaretta ${ }^{1}$, Luiz Prudêncio Santos ${ }^{2}$, Ana Maria Barbosa ${ }^{3}$, Stephen Hyslop ${ }^{4}$, Alexandre Pinto Corrado $^{5}$, Milene Sanches Galhardo ${ }^{6}$, Renata Amadei Nicolau ${ }^{7 *}$, José Carlos Cogo ${ }^{1}$

${ }^{1}$ Laboratório de Fisiologia e Farmacodinâmica, Instituto de Pesquisa e Desenvolvimento - IP\&D, Universidade do Vale do Paraíba - UNIVAP, São José dos Campos, SP, Brazil.

${ }^{2}$ Escola de Enfermagem Wenceslau Braz - EEWB, Itajubá, MG, Brazil.

${ }^{3}$ Faculdade Anhanguera Taubaté, Taubaté, SP, Brazil.

${ }^{4}$ Departamento de Farmacologia, Faculdade de Ciências Médicas, Universidade Estadual de Campinas - UNICAMP, Campinas, SP, Brazil.

${ }^{5}$ Departamento de Farmacologia, Faculdade de Medicina de Ribeirão Preto, Universidade de São Paulo - USP, Ribeirão Preto, SP, Brazil.

${ }^{6}$ Laboratório de Histologia, Instituto Básico de Biociências, Universidade de Taubaté - UNITAU, Taubaté, SP, Brazil.

${ }^{7}$ Centro de Laserterapia e Fotobiologia, Instituto de Pesquisa e Desenvolvimento - IP\&D, Universidade do Vale do Paraíba - UNIVAP, Avenida Shishima Hifumi, 2911, Bairro Urbanova, CEP 12244-000, São José dos Campos, SP, Brazil.
} 